\title{
Working
}

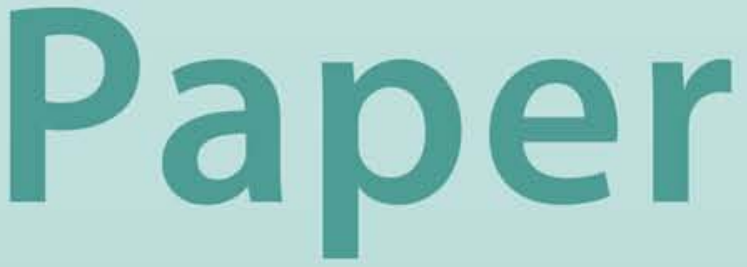


Corporate Governance Reforms in the EU:

Do They Matter and How?

Iryna Ivaschenko and Petya Koeva Brooks 


\title{
IMF Working Paper
}

\author{
European Department
}

\section{Corporate Governance Reforms in the EU: Do They Matter and How?}

\author{
Prepared by Iryna Ivaschenko and Petya Koeva Brooks*
}

Authorized for distribution by James Daniel and Jörg Decressin

April 2008

\begin{abstract}

\section{This Working Paper should not be reported as representing the views of the IMF.}

The views expressed in this Working Paper are those of the authors and do not necessarily represent those of the IMF or IMF policy. Working Papers describe research in progress by the authors and are published to elicit comments and to further debate.

This paper proposes a new approach to quantifying the effects of corporate governance reforms, by focusing on the dynamics of the voting premiums, a measure of the private benefits of control in a corporation. The results indicate that the reforms have been successful in reducing the voting premiums EU-wide. Moreover, more intense and broad reform efforts (such as introducing national reforms beyond and above the EU-wide initiatives) bring higher and longer lasting benefits. Our findings also suggest that the market for corporate control in Europe has become more integrated, as illustrated by the lower dispersion in voting premiums across countries and over time.
\end{abstract}

JEL Classification Numbers: G30, G38, L51

Keywords: corporate governance, reforms, voting premiums, integration

Authors’ E-Mail Addresses: iivaschenko@imf.org; pkoeva@imf.org

\footnotetext{
* The authors would like to thank Helge Berger, Marcello Bianchi, Magda Bianco, James Daniel, Jörg Decressin, Gianni De Nicoló, Luca Enriques, Ben Hunt, Dora Iakova, and the seminar participants at the Bank of Italy and the IMF for useful comments; and Craig Dodge for helpful insights on constructing the data set. All remaining errors are our own.
} 


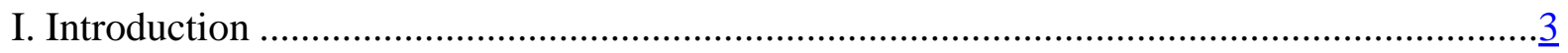

II. National and EU Corporate Governance Reforms ............................................................... $\underline{5}$

A. National Reforms ...........................................................................................

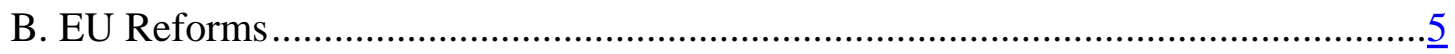

III. Measuring the Private Value of Control .............................................................................

IV. Data and Methodology …………….........................................................................

A. Data Sample and Descriptive Statistics ................................................................

B. Empirical Strategy ………………………………………..............................

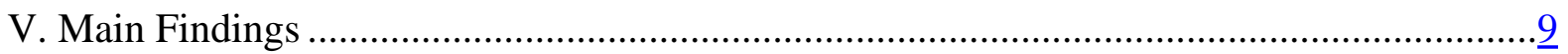

A. Voting Premiums Across Time and Countries ......................................................... 9

B. Have Reforms Reduced the Private Benefits of Control?.........................................10

C. Have Reforms Brought About Convergence in Corporate Control? .........................11

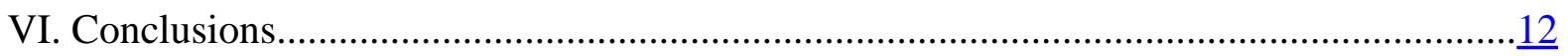

Tables

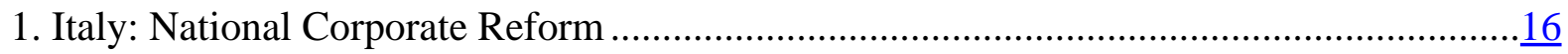

2. Germany: National Corporate Governance Reforms........................................................17

3. France: National Corporate Governance Reforms............................................................18

4. EU Corporate Governance Reforms ...............................................................................19

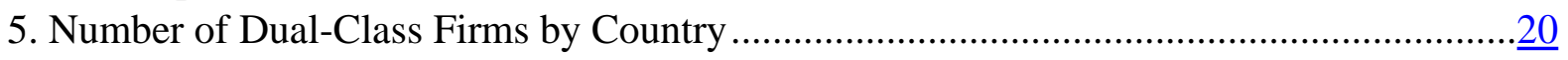

6. Voting Premium: Summary Statistics...........................................................................

7. Voting Premiums Year Effects ........................................................................................

8. Voting Premium Distributed Year Effects............................................................................

9. Relative Effectiveness of Reforms in C3 Compared to the EU and Non-EU Peers, by Year.................................................................................22

10. Relative Effectiveness of Reforms Compared to Control Groups: A Summary …….........르

11. Voting Premiums: Year Effects, Accounting for Product Market Reforms ........................23

12. Relative Effectiveness of Reforms in C3 Compared to the EU and Non-EU Peers, Accounting for Product Market Reforms, by Year.............................................................

13. Distribution Characteristics of Voting Premiums, Pooled for All EU Countries ................25

Figures

1. Dynamic of the Voting Premiums Acorss Countries, 1992-2007........................................26

2. Reform Efforts: Number of Important Corporate Governance Reforms Per Year................27

3. Number of National and EU Corporate Governance Reforms .............................................28

4. Convergence in Voting Premiums Across Countries .........................................................28

5. Distribution of Voting Premium Across EU Countries, by Year ……………………….....29

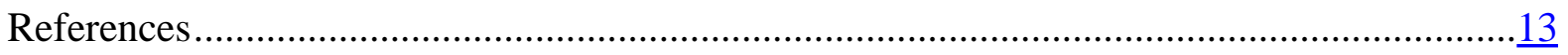




\section{INTRODUCTION}

The significance of corporate governance has become well recognized in recent years. ${ }^{1}$ Corporate governance is often defined as the system by which companies are directed and controlled for the benefit of shareholders. Better governance practices allow firms to access capital markets on better terms and can lead to higher firm valuation, rates of return, and performance. By mitigating the misalignment of incentives (i.e., the "agency problem”) among shareholders and between shareholders and managers, better governance can also reduce the scope for undertaking inefficient investments-and therefore, boost growth. ${ }^{2}$ Moreover, integration and convergence in the corporate governance environment and the market for corporate control are an important transmission channel of organizational and technological innovations across countries. ${ }^{3}$

A key notion in the corporate governance literature is the private benefits of control. ${ }^{4}$ The separation of ownership and control in the corporation gives rise to agency problems that have been studied extensively in the theoretical and empirical literature. ${ }^{5}$ In this context, the private benefits of control are defined as the value that controlling shareholders can extract to the detriment of minority shareholders. Institutional factors that determine the private benefits of control include the legal environment (i.e., the degree of investor protection, the strength of public and private enforcement), takeover rules, corporate charter provisions, etc. For example, weaker insider trading legislation and enforcement have been linked to higher cost of capital (Bhattacharya and Daouk, 2002), while poor protection of minority investors by the legal environment has been associated with less developed financial markets (La Porta, et al, 2002).

The past decade witnessed a wave of corporate governance reforms in Europe, aimed at reducing the power of dominant shareholders and fostering integration of the market for corporate control. At the national level, reforms were particularly far-reaching in three major countries (France, Germany, and Italy), with the objective of raising the efficiency and

\footnotetext{
${ }^{1}$ In the words of Shleifer and Vishny (1997), "corporate governance deals with the ways in which suppliers of finance to corporations assure themselves of getting a return on their investment."

${ }^{2}$ Recent studies on this topic include Dittmar and Mahrt-Smith (2006), Bruno and Claessens (2006), Chhaochharia and Laeven (2007), and De Nicoló, et al (2007). A review of the literature is available in Becht, et al (2003) and Dennis and McConnell (2003), for example.

${ }^{3}$ For example, see Gertler (2001) and Leyshon and Pollard (2000).

${ }^{4}$ Control is defined as the ownership of a sufficient voting power to make decisions on company matters (Nenova, 2003).

${ }^{5}$ See Jensen and Meckling (1976), Grossman and Hart (1988), Johnson, et al (2000), Lombardo and Pagano (2002), La Porta, et al (2002), Stulz (2005) on the theoretical side and Claessens, et al (1999), and La Porta, et al (2000) on the empirical side.
} 
competitiveness of the corporate sector in these countries and to increase investor protection. Other reforms were initiated at the EU level to integrate and harmonize company law and corporate governance across countries, with the ultimate goal of promoting a fully integrated European capital market. To some extent too, the reforms were also in response to major U.S. and European corporate scandals. ${ }^{6}$ Key elements of both sets of reforms were to empower minority shareholders, improve internal governance, enhance disclosure requirements, and strengthen public enforcement (Enriques and Volpin, 2007). The underlying objectives were to decrease the power of dominant shareholders - and, therefore, the private benefits of corporate control —and to promote integration and harmonization of national corporate governance regimes.

This paper poses two main questions. First, have corporate governance reforms succeeded in improving corporate governance and curbing the power of dominant shareholders in Europe? (Or, put differently, is there evidence that the reforms have reduced the private benefits of control?) Has the improvement (if any) been larger in countries that implemented their own reforms on top of those of the EU? Second, have the reforms achieved a de facto convergence in corporate governance regimes, as proxied by the private benefits of control, and integration in the market for corporate control in Europe?

The main contribution of this paper is to address these questions quantitatively, using a financial market-based proxy for the private benefits of corporate control. As the private benefits of control are generally unobservable, their measurement is difficult. But it is not impossible: when a firm has more than two classes of publicly traded shares with different voting rights, the percentage difference between the prices of high- and low-voting shares is called the "voting premium" and can be used as a proxy for the private benefits of control (Nenova, 2003; Doidge, 2004). If the reforms were effective, the value of corporate control should diminish, and the voting premium should fall. The observed decline, if any, should be more pronounced in countries that implemented both EU and national reforms than in countries that introduced EU reforms only. In addition, the dispersion of voting premiums should decline, indicating that the private benefits of corporate control have converged across countries, i.e., that the market for corporate control in Europe has become more integrated. To our knowledge, our paper is the first one to use the voting premium in this context.

The rest of the paper is organized as follows. The next section outlines the main corporate governance reforms implemented at the national level (in France, Germany, and Italy) and at the EU level. Section III explains how the corporate value of control is measured in this paper. Section IV describes the methodology and data used in the analysis. Section V presents the main findings. Section VI concludes.

\footnotetext{
${ }^{6}$ Such as Enron, Parmalat, and Cirio.
} 


\section{NATIONAL AND EU CORPORATE GOVERNANCE REFORMS}

\section{A. National Reforms}

Over the past decade, the three largest economies in continental Europe (Italy, Germany, and France) have introduced numerous corporate governance reforms to protect investors. The key initiatives in this core group of countries (C3) are summarized in Tables 1-3. As discussed in Enriques and Volpin (2007), the reforms have focused on increasing investor protection in four areas:

- Empowering minority shareholders. In this area, key initiatives have been to give greater voice to shareholders, improve private enforcement, introduce new rules promoting "one-share one-vote" and control transactions (e.g., implementing a "mandatory bid" rule that requires the party that obtains a controlling block of the shares to offer to acquire the rest of the shares at above market price).

- Enhancing internal governance. The focus has been on making corporate boards more effective and tightening rules on third-party transactions (e.g., requiring board members to disclose to any interest, direct or indirect, in a transaction).

- Improving disclosure requirements. The actions taken in this area have been to introduce (or update) corporate governance codes and implement new, more stringent rules on self-dealing and compensation, as well as financial reporting and audit.

- Strengthening public enforcement. Reform efforts have included giving more powers to the supervisory authority, introducing sanctions against market abuse, and enforcing rules on financial reporting auditing.

\section{B. EU Reforms}

In addition to curbing the power of dominant shareholders, EU reforms focused on harmonizing and integrating company law and corporate governance across countries (European Commission, 2003; Enriques and Gatti, 2006). In fact, the number of EU regulations and directives on corporate governance increased dramatically in the early 2000 (see chart). Prominent examples include the Transparency Directive, the Market Abuse Directive, the Prospectus Directive, a regulation on the application of international accounting standards, IAS/IFRS. (A more comprehensive list of reforms is included in Table 4). Although to some extent these efforts were in response to major U.S. and European scandals, most measures were implemented as part of the Financial Services Action Plan, with the underlying objective of promoting a fully integrated European capital market.

To what extent the EU (and national) reforms have succeeded in bringing about convergence in corporate governance regimes and integration of the market for corporate control is an 
open question. In this context, it is important to distinguish between de jure and de facto convergence in corporate governance standards. The bulk of evidence on de jure convergence is substantial (Mallin, 2002; Wymeersch, 2002), including in controversial areas such as takeover regulation (Goergen, Martynova, and Renneboog, 2005). The evidence on de facto convergence is more scarce and often indirect, however. Some papers focus on the evolution of ownership structures in large European countries and shows that they exhibit a falling degree of concentration. ${ }^{7}$ Others contain case studies of individual countries (Germany, France). ${ }^{8}$ The most concrete empirical evidence comes from examining the evolution of corporate governance ratings of large European companies between 2000 and 2003, which suggests certain ratings (for board structure and disclosure) have converged across countries and over time (Wojcik, 2006). Therefore, to the best of our knowledge, this paper uses a novel approach to answer the question of whether there is de facto corporate governance convergence in Europe.

\section{Measuring the Private Value of Control}

Measuring the value of corporate control is difficult by definition. Specifically, the right to control a corporation is valuable because it provides controlling agents with opportunities to extract private benefits, a concept that is difficult to standardize and measure. Nevertheless, two methods have been proposed in the literature to tackle this measurement problem. The first infers the value of control from the voting premium embedded in the valuation of different types of shares issued by dual-class firms (e.g., Lease, et al, 1983, 1984; Zingales, 1994, 1995; Nenova, 2003; and Doidge, 2004). The second method measures the difference between prices of shares in control blocks and the regular shares (Dyck and Zingales, 2002).

We focus on the voting premium method, as data on dual-class firms are relatively easy to obtain. Following the approach of Nenova (2003) and Doidge (2004), we collect data on a large sample of European and Canadian firms with dual-class shares. In particular, following Doidge (2004), the voting premium is defined as the ratio of the price of a voting right (highvoting share, $\mathrm{P}_{\mathrm{H}}$ ) to the price of a cash flow right (low-voting share, $\mathrm{P}_{\mathrm{L}}$ ):

$$
\mathrm{VP}=\left(\mathrm{P}_{\mathrm{H}}-\mathrm{P}_{\mathrm{L}}\right) / \mathrm{P}_{\mathrm{L}}
$$

This definition of the voting premium is comparable across firms with different voting arrangements, which is especially important for cross-country comparisons. Moreover, although the voting premium as defined above may be biased upward (because it is calculated from prices set by minority shareholders rather than by those in control), it is still suitable for time-series analysis.

\footnotetext{
${ }^{7}$ See Van der Elst (2000) and Wojcik (2003).

${ }^{8}$ O’Sullivan (2003) and Vitols (2003).
} 
Also, equation (1) is the most straightforward definition of the voting premium. More sophisticated measures used in the literature involve weighing the prices of high-and lowvoting shares by the relative number of votes per each class of share and by the number of shares outstanding for each class (e.g., Nenova, 2003). However, Doidge (2004) shows that different measures of the voting premium do not change the time-series and cross-firm comparison results. Hence, we concentrate on the simplest measure as defined in (1).

\section{DATA AND Methodology}

\section{A. Data Sample and Descriptive Statistics}

The sample is constructed by analyzing all firms included in the country lists provided by DataStream from 1992 to 2007. The companies comprising the sample satisfy the following criteria: ${ }^{9}$ (a) they have at least two classes of shares with different voting rights; (b) both share classes are publicly traded; (c) the low-voting class is not convertible into the highvoting class; (d) neither class receives a fixed dividend, which is independent of the other class; and (e) neither class is redeemable or callable by the company.

The data are collected for nine (EU and non-EU) industrialized countries that allow dual shares and are presented in DataStream (France, Germany, Italy, Denmark, Finland, Sweden, U.K., Norway, and Canada). ${ }^{10}$ After imposing these criteria, a sample of 342 firms is selected. The number of dual-share companies varies greatly across the core group: from more than 80 in Italy and 68 in Germany to 15 in France (Table 5). Each country in the control group has at least 20 dual-class firms. Although the long sample effectively corrects for survivorship bias, ${ }^{11}$ we further eliminate it by including both actively traded shares and shares that have been withdrawn from the market or expired.

For each share, Wednesday-to-Wednesday weekly closing data on share prices and other control variables are collected from the DataStream and Bloomberg for the period from January 1, 1992 to December 31, 2007..$^{12}$ The voting premium is calculated using equation (1) for each firm for the entire time period and then averaged for each year to isolate temporary price shocks related to market and company news. If there is more than one pair of

\footnotetext{
${ }^{9}$ See Nenova (2003) and Doidge (2004) for more details.

${ }^{10}$ Spain is not included in the sample because, although dual-class share is allowed in Spain, none is covered in the DataStream country lists. The U.S. dataset is under construction.

${ }^{11}$ See Nenova (2003).

${ }^{12}$ The use of the weekly Wednesday-to-Wednesday data is common in the finance literature to mitigate the Monday effect.
} 
voting and nonvoting shares satisfying conditions (a)-(e) for a given company, we choose the pair that has the closest characteristics except for the difference in the voting rights. ${ }^{13}$

\section{B. Empirical Strategy}

To address the first question of whether reforms have affected the private value of control, we first examine the dynamics of the voting premium for each country in the core group (France, Germany, and Italy) during the period 1992-2007. The relationship between the evolution of the premium and the reforms initiated at the EU and national levels in these countries is then compared with the trends in two control groups comprising EU (Finland, Denmark, Sweden, U.K.) and non-EU countries (Norway, Canada), respectively. The control groups were comprised of the countries for which the data satisfying the filtering requirements were available (see the previous section on the data selection process), and which appear to have had fewer reforms during the sample period considered compared to the core group.

The analysis is conducted within a panel regression framework, using two empirical specifications.

The first specification allows to test whether the voting premium declines by more following a reform-heavy year (captured by a time dummy) than before and after it. To do this, a oneyear lead of the (firm-specific) observation for the voting premium is regressed on country dummies, year dummies, and firm-specific fixed effects. The country-specific fixed effects are included because they are the most important determinant accounting for the crosscountry variation of the voting premium (Doidge, 2004). ${ }^{14}$ The firm-level fixed effects are added in order to account for other firm-level factors may affect the voting premium. Hence, including both effects allows to use the most parsimonious specification:

$$
V P_{i, t, y+1}=\sum_{c=1}^{9} \alpha_{c} D_{c}+\sum_{y=1992}^{2006} \beta_{y} D_{y}+\delta_{i}+\varepsilon_{i t} \text {, }
$$

where $V P_{i, t, y+1}$ is a weekly voting premium for a company $i$, year $y+1 ; D_{c}$ is a country dummy, for c $\subset(1 ; 9)$ (1 = Canada, 2 = Denmark, 3 = Finland, $4=$ France, 5 = Germany, $6=$

\footnotetext{
${ }^{13}$ See Doidge (2004) for details.

${ }^{14}$ Other factors that could affect the voting premium include differences in voting power, liquidity, and the firm size (Doidge, 2004 and references therein). Hence, our regressions include firm-specific fixed effects to proxy for these factors. In addition, firm-specific effects could capture changing nature of firms with dual class shares in the sample.
} 
Italy, 7 = Norway, $8=$ Sweden, $9=$ U.K.), $D_{y}$ is a year dummy, for $y \subset(1992 ; 2006), \delta_{i}$ is a firm-specific fixed effects, and $\varepsilon_{i t}$ is a residual.

The second specification also includes interaction terms between the country and time dummies, (in addition to the above regressors) in order to test whether the change in the voting premium in a given C3 country is significantly different from that in the two control groups:

$$
V P_{i, t, y+1}=\sum_{c=1}^{9} \alpha_{c} D_{c}+\sum_{y=1992}^{2006} \beta_{y} D_{y}+\sum_{c=1}^{9} \sum_{y=1992}^{2006} \lambda_{c, y} D_{c, y}+\delta_{i}+\varepsilon_{i t},
$$

where $D_{c, y}$ is an interaction term between each country and year dummy, respectively.

To answer the second question of whether reforms have been associated with a convergence in the value of corporate control across the EU, we proceed in two steps:

First, the (constructed) country series for the voting premium are used to gauge the degree of convergence in corporate control levels across the seven EU countries in the sample. This is done by computing the standard deviation of the country-specific voting premiums for each year in the sample. Significant reductions in these parameters would indicate that the values of corporate control have converged across EU countries.

Second, for each year, all firm-level observations are pooled together across countries, in order to construct an overall distribution of voting premiums for the given year. The evolution of this distribution can be tracked over the period 1992-2007. A compression of the distribution over time would imply that the voting premiums in the EU are becoming increasingly similar in magnitude.

\section{MAIN FINDINGS}

\section{A. Voting Premiums Across Time and Countries}

The voting premium varies widely across countries (Table 6). Calculated as the average over the 1992-2007 period, the premium is the highest in France and Italy, at 50 and 46 percent, respectively, while Germany, with 11 percent, is at the lower range of the spectrum, on par with Denmark, Finland, and Canada. The premium is the lowest in Scandinavian countries, with both Sweden and Norway below 1 percent. These results are in line with previous studies by Zingales (1994), Amoako-Adu (1995), and Doidge (2004). The average U.K. voting premium is somewhat higher than that found in the earlier studies (13 to 16 percent) because this paper uses more recent data and reflects a recent upward trend in the U.K. premium.

Voting premiums in the C3 countries significantly declined over the past 15 years (Figure 1). Germany, Italy, and France experienced dramatic drops in the voting premiums. 
Improvements in Italy are especially notable-from an clear outlier (voting premium above 100 percent) in the early 1990s to just above 20 percent level in 2007. While it is difficult to precisely time the effects of corporate governance reforms, at a first glance, the general downward trend in the C3 countries seems to be consistent with efforts in this area on both EU and national levels.

\section{B. Have Reforms Reduced the Private Benefits of Control?}

Turning to the econometric evidence, we find that corporate governance reform efforts have been associated with a decline in voting premiums. Taking into account reforms introduced at the national level in the $\mathrm{C} 3$ group and EU-wide initiatives, the most reform-heavy years are 1998 and 2001-05 (Figures 2 and 3). Panel data estimates, which control for firm-specific and country-specific effects, suggest that, on average, greater reform efforts are indeed associated with a substantial reduction in the voting premium in the following year as indicated by the larger negative (and statistically significantly larger) coefficients on dummy variables for 1998 and 2001-05 years (compared to the coefficients for the preceding and following years (Table 7)). In addition, the regression results imply that deeper reform effort is associated with longer lasting reduction in the voting premiums, as measured by coefficients on the two- and three-year lead of the voting premiums as a dependent variable (Table 8).

The estimation results also indicate that, in general, broad corporate governance reforms have been effective in reducing the private benefits of control in the C3 countries more than in the control groups (Tables 9 and 10). In particular, the coefficients on the interaction dummies between countries and years are generally significant and of the negative sign, indicating a larger reduction of voting premiums for the $\mathrm{C} 3$ countries. This is true for all years with significant reforms, with the exception of 1998 for Germany and France and 2001 for Germany, where coefficients are negative but not significant. Results for Italy are particularly impressive, with higher and significant coefficients for all "reform-heavy" years. At the same time, results for the EU control group are mostly insignificant, and the only significant coefficient for the non-EU control group, for 2006, is of positive sign, indicating an increase in the voting premiums. While these findings may be partially driven by the high initial voting premiums in Italy, and to a lesser extent, France, they do indicate that the extra reform effort pays off.

To be sure, disentangling the effects of the EU-wide and national-level reforms is complicated and requires further research on the interaction effects between various 
reforms. ${ }^{15}$ However, the fact that the reduction in voting premiums has been the most pronounced in Germany, France, and Italy right after the years when the countries introduced significant reforms beyond and above the EU-wide initiatives suggests a positive payoff from the extra reform effort.

In addition, the results are robust to accounting for other reforms that could have reduced premiums. In particular, product market reforms (with the increase in competition that has followed the opening up of national European markets starting in 1992) might have reduced the rents that can be misappropriated by controlling shareholders, thereby reducing the premium. To account for this, the specifications (2) and (3) were also estimated including the index of product market reforms, as in Berger and Danninger (2006), for example. The results, presented in Tables 11 and 12 indicate that even after accounting for other reforms, voting premiums declined by more after the reform-heavy years, and the declines are more pronounced in the C3 countries as compared to control groups. ${ }^{16}$

The analysis also suggests that the EU-wide reform efforts have been associated with a consistent downward trend in voting premiums within the Union. At the same time, voting premiums were flat and even edged up lately in the countries outside the Union included in the sample, namely Canada and Norway.

\section{Have Reforms Brought About Convergence in Corporate Control?}

Turning to the convergence question, we find that corporate control premiums have become increasingly compressed across countries. In particular, the standard deviation of the country voting premiums has an initial value of 0.43 in 1992, but it falls to 0.17 in 1998-99 from 0.22-0.26 in 1995-97 (Figure 4) The timing of the decline broadly coincides with the period of EU and national level reforms, suggesting that reform efforts may have contributed to the convergence in the value of corporate control across Europe.

The findings from pooling all firm-specific observations in a given year from the EU countries in the sample paint a similar picture. The evolution of the distribution of voting premiums in EU countries is presented in Figure 5. The parameters of the annual

\footnotetext{
${ }^{15}$ In addition, voting premiums might have been affected by global market developments. For example, the entrance of U.S. investment banks into continental Europe markets, together with U.S. and U.K. law firms, might have had an impact on how firms structure their transactions. Furthermore, the greater presence of large international institutional investors in the capital of European companies might deter private benefits extraction to some degree, by prompting issuers to adopt self-regulatory or even firm-level "reforms" of corporate governance practices.

${ }^{16}$ Labor market reforms might also affect voting premiums, for example through changing firms' dividend policies. However, data limitations did not allow us to incorporate indices of labor market reforms in the estimations. In fact, such indices are only available at discrete time points, such as end 1980s, end 1990s, and 2003, and many authors simply used interpolation techniques to obtain continuous time series (see, for example, Fiori, et al, 2008).
} 
distributions are shown in Table 9. The results indicate that the distribution has become tighter (more compressed) over time, lending support to the notion that the private benefits of corporate control have converged, in tandem with the reform initiatives at the EU and national levels.

\section{Conclusions}

This paper proposes a new approach to quantifying the effects of corporate governance reforms, by focusing on the dynamics of the voting premiums, a measure of the private benefits of control in a corporation. After constructing voting premiums based on financial market data, it assesses the impact of reforms on the value of control in nine industrialized countries and analyzes the effect of national reforms in three large European countriesFrance, Germany, and Italy — as compared to their EU and non-EU peers. The paper also investigates whether voting premiums have converged across countries and over time, in tandem with reform efforts.

The results indicate that the reforms have been successful in reducing the voting premiums EU-wide, and the results are especially strong in the C3 countries. For example, Italy witnessed a spectacular reduction in voting premiums over the past 15 years. Moreover, more intense and broader reform efforts (such as introducing national reforms beyond and above the EU-wide initiatives) bring higher and longer lasting benefits. The empirical findings also suggest that the market for corporate control in Europe has become more integrated, as illustrated by the lower dispersion in voting premiums across countries and over time. 


\section{References}

Becht, M., and C. Mayer, 2001, The Corporate Control of Corporate Europe (Oxford: Oxford University Press.)

Berger, H., and S. Danninger, 2006, “The Employment Effects of Labor and Product Markets Deregulation and their Implications for Structural Reforms,” CESifo Working Paper No. 1709.

Bhattacharya, U., and H. Daouk, 2002, “The World Price of Insider Trading,” Journal of Finance, Vol. 57, pp. 75-108.

Bruno, V., and S. Claessens, 2007, “Corporate Governance and Regulation: Can There Be Too Much of a Good Thing?” CEPR Discussion Paper No. 6108.

Chhaochharia, V., and L. Laeven, 2007, “The Invisible Hand in Corporate Governance,” ECGI Finance Working Paper No. 165 (European Corporate Governance Institute).

De Nicoló, G., L. Laeven, and K. Ueda, 2008, “Corporate Governance Quality: Trends and Real Effects,” Journal of Financial Intermediation, doi:10.1016/j.jfi.2007.10.002.

Denis, M., and J. McConnell, 2003, “International Corporate Governance,” ECGI Working Paper No. 05, pp. 1-62.

Dittmar, A., and J. Mahrt-Smith, 2007, “Corporate Governance and the Value of Cash,” Journal of Financial Economics, Vol. 83, pp. 599-634.

Doidge, Craig, 2004, “U.S. Cross-Listings and the Private Benefits of Control: Evidence from Dual-Class Firms,” Journal of Financial Economics, Vol. 72, pp. 519-53.

Dyck, A., and L. Zingales, 2004, "Private Benefits of Control: An International Comparison,” Journal of Finance, Vol. 59, pp. 537-600.

Enriques, L., and M. Gatti, 2006, “EC Reforms of Corporate Governance and Capital Markets Law: Do They Tackle Insiders’ Opportunism?” Available via the Internet: http://papers.ssrn.com/sol3/papers.cfm?abstract_id=886345.

Enriques, L., and P. Volpin, 2007, “Corporate Governance Reforms in Continental Europe,” Journal of Economic Perspectives, Vol. 21, pp. 117-40. 
European Commission, 2003, Modernizing Company Law and Enhancing Corporate Governance in the European Union-A Plan to Move Forward. Available via the Internet: http://ec.europa.eu/internal_market/company/news/index_en.htm.

Fiori, G., G. Nicoletti, S. Scarpetta, and F. Schiantarelli, 2008, “Employment Outcomes and the Interaction Between Product and Labor Market Deregulation: Are They Substitutes or Complements?" presented at the IMF conference "On Causes and Consequences of Structural Reforms” (February 28-29).

Goergen, M., M. Martynova, and L. Renneboog, 2005, "Corporate Governance Convergence: Evidence from Takeover Regulation Reforms,” ECGI Working Paper No. 33.

Grossman, S., and O. Hart, 1988, "One Share-One Vote and the Market for Corporate Control,” Journal of Financial Economics, Vol. 20, pp.175-202.

Jensen, M., and W. Meckling, 1976, "Theory of the Firm: Managerial Behavior, Agency Costs, and Ownership Structure,” Journal of Financial Economics, Vol.3, pp. 305-60.

Johnson, S., R. La Porta, F. Lopez-de-Silanes, and A. Shleifer, 2000, “Tunnelling,” American Economic Review, Vol. 90, pp. 22-27.

La Porta, R., F. Lopez-de-Silanes, A. Shleifer, and R. Vishny, 1997, "Legal Determinants of External Finance,” Journal of Finance, Vol. 52, pp. 1131-50.

La Porta, R., F. Lopez-de-Silanes, and A. Shleifer, 2002, "Investor Protection and Corporate Valuation,” Journal of Finance, Vol. 57, pp. 1,147-70.

Lease, R., J. McConnell, and W. Mikkelson, 1983, “The Market Value of Control in Publicly Traded Corporations,” Journal of Financial Economics, Vol. 2, pp. 439-71.

Leyshon, A., and J. Pollard, 2000, "Geographies of Industrial Convergence: The Case of Retail Banking,” Transactions of the Institute of British Geographers, Vol. 25, pp. 203-20.

Mallin, C., 2004, Corporate Governance (Oxford: Oxford University Press).

Nenova, Tatiana, 2003, "The Value of Corporate Voting Rights and Control: A CrossCountry Analysis,” Journal of Financial Economics, Vol. 68, pp. 325-51. 
Shleifer, A., and R. Vishny, 1997, “A Survey of Corporate Governance,” Journal of Finance, Vol. 52, pp. 737-83.

Smith, B., and B. Amoako-Adu, 1995, "Relative Prices of Dual Class Shares,” Journal of Financial and Quantitative Analysis, Vol. 30, pp. 223-39.

Stulz, R., 2005, “The Limits of Financial Globalization,” Journal of Finance, Vol. 60, pp. 1,595-638.

Van der Elst, C., 2000, “The Equity Markets, Ownership Structures and Control: Towards an International Harmonization?” Financial Law Institute Working Paper No. 4.

Wojcik, D., 2003, “Change in the German Model of Corporate Governance: Evidence from Blockholdings 1997-2001,” Environment and Planning, Vol. 35, pp. 381-87.

— 2006 , “Convergence in Corporate Governance: Evidence from Europe and the Challenge for Economic Geography,” Journal of Economic Geography, pp.639-60.

Wymeersch, D., 2002, “Convergence or Divergence in Corporate Governance Patterns in Western Europe,” Corporate Governance Regimes: Convergence and Diversity, ed. by J. Mcahery, et al (Oxford: Oxford University Press).

Zingales, L., 1994, "The Value of the Voting Right: A Study of the Milan Stock Exchange Experience,” Review of Financial Studies, Vol. 7, pp. 125-48. 
Table 1. Italy: National Corporate Governance Reforms

\begin{tabular}{|c|c|c|c|}
\hline Year & Reform content & Specific area & General area \\
\hline 1991 & Criminal sanctions for insider trading & Sanctions & Public enforcement \\
\hline 1998 & $\begin{array}{l}\text { New rules on board's information } \\
\text { Minorities represented in board of auditors and in board of directors } \\
\text { Greater role and powers for board of auditors and stricter independence requirements for its members } \\
\text { Lower thresholds for minority shareholder rights } \\
\text { Limits on validity of shareholder agreements } \\
\text { Deriviative suits for minorities representing at least } 2.5 \text { percent of shares allowed } \\
\text { Mandatory bid rule } \\
\text { Increased cooperation between supervisory board and auditor } \\
\text { Increased regulator's investigative and sanctioning powers } \\
\text { Criminal sanctions for market manipulation }\end{array}$ & $\begin{array}{l}\text { Board effectiveness } \\
\text { Board effectiveness } \\
\text { Board effectiveness } \\
\text { Greater voice for shareholders } \\
\text { One-share one-vote rules } \\
\text { Private enforcement } \\
\text { Control transactions } \\
\text { Financial reporting and audit } \\
\text { Powers of supervisory authority } \\
\text { Sanctions }\end{array}$ & $\begin{array}{l}\text { Internal governance } \\
\text { Internal governance } \\
\text { Internal governance } \\
\text { Shareholder empowerment } \\
\text { Shareholder empowerment } \\
\text { Shareholder empowerment } \\
\text { Shareholder empowerment } \\
\text { Disclosure } \\
\text { Public enforcement } \\
\text { Public enforcement }\end{array}$ \\
\hline 1999 & Annual disclosure of individual directors' compensation & Self-dealing and compensation & Disclosure \\
\hline 2002 & Immediate disclosure of material related-party transactions & Self-dealing and compensation & Disclosure \\
\hline 2003 & $\begin{array}{l}\text { New rules on board's information } \\
\text { Increased board disclosure and procedural requirements on related-party transactions } \\
\text { Exercise of voting rights made easier } \\
\text { Voting caps banned } \\
\text { Sale of corporate shareholdings tax-exempt } \\
\text { Direct shareholder suit against parent company for damages stemming from abuse of corporate control }\end{array}$ & $\begin{array}{l}\text { Board effectiveness } \\
\text { Internal governance and self-dealing } \\
\text { Greater voice for shareholders } \\
\text { One-share one-vote rules } \\
\text { One-share one-vote rules } \\
\text { Private enforcement }\end{array}$ & $\begin{array}{l}\text { Internal governance } \\
\text { Internal governance } \\
\text { Shareholder empowerment } \\
\text { Shareholder empowerment } \\
\text { Shareholder empowerment } \\
\text { Shareholder empowerment }\end{array}$ \\
\hline 2005 & $\begin{array}{l}\text { Minorities represented in board of auditors and in board of directors } \\
\text { Greater role and powers for board of auditors and stricter independence requirements for its members } \\
\text { Shareholder approval of stock-based compensations } \\
\text { Lower thresholds for minority shareholder rights } \\
\text { Deriviative suits for minorities representing at least } 2.5 \text { percent of shares allowed } \\
\text { Corporate governance code mandated on a comply-or-explain basis } \\
\text { Audit partner rotation, } 6 \text { years, and firm rotation, } 12 \text { years } \\
\text { Prohibition on nonaudit services to audit clients } \\
\text { General manager's and CFO's statement on truth of financial reports and adequacy of accounting procedures } \\
\text { Increased regulator's investigative and sanctioning powers } \\
\text { Securities' agency review of financial reports } \\
\text { Securities' agency powers on audit firms strengthened }\end{array}$ & $\begin{array}{l}\text { Board effectiveness } \\
\text { Board effectiveness } \\
\text { Greater voice for shareholders } \\
\text { Greater voice for shareholders } \\
\text { Private enforcement } \\
\text { Corporate governance } \\
\text { Financial reporting and audit } \\
\text { Financial reporting and audit } \\
\text { Financial reporting and audit } \\
\text { Powers of supervisory authority } \\
\text { Enforcing reporting and auditing rules } \\
\text { Enforcing reporting and auditing rules }\end{array}$ & $\begin{array}{l}\text { Internal governance } \\
\text { Internal governance } \\
\text { Shareholder empowerment } \\
\text { Shareholder empowerment } \\
\text { Shareholder empowerment } \\
\text { Disclosure } \\
\text { Disclosure } \\
\text { Disclosure } \\
\text { Disclosure } \\
\text { Public enforcement } \\
\text { Public enforcement } \\
\text { Public enforcement }\end{array}$ \\
\hline 2006 & Contingency fees allowed & Private enforcement & Shareholder empowerment \\
\hline
\end{tabular}

Source: Enriques and Volpin (2007). 
Table 2. Germany: National Corporate Governance Reforms

\begin{tabular}{|c|c|c|c|}
\hline Year & Reform content & Specific area & General area \\
\hline 1994 & $\begin{array}{l}\text { Securities regulator set up } \\
\text { Criminal sanctions for insider trading }\end{array}$ & $\begin{array}{l}\text { Powers of supervisory authority } \\
\text { Sanctions against market abuse }\end{array}$ & $\begin{array}{l}\text { Public enforcement } \\
\text { Public enforcement }\end{array}$ \\
\hline 1998 & $\begin{array}{l}\text { Greater role for supervisory board } \\
\text { Specific duties on risk management and internal controls } \\
\text { Multiple voting shares banned and banks' influence over shareholder meetings curbed } \\
\text { Increased cooperation between supervisory board and auditor } \\
\text { Audit partner rotation, } 7 \text { years }\end{array}$ & $\begin{array}{l}\text { Board effectiveness } \\
\text { Board effectiveness } \\
\text { One-share one-vote rules } \\
\text { Financial reporting and auditing } \\
\text { Financial reporting and auditing }\end{array}$ & $\begin{array}{l}\text { Internal governance } \\
\text { Internal governance } \\
\text { Shareholder empowerment } \\
\text { Disclosure } \\
\text { Disclosure }\end{array}$ \\
\hline 2001 & Exercise of voting rights made easier & Greater voice for shareholders & Shareholder empowerment \\
\hline 2002 & $\begin{array}{l}\text { Sale of corporate shareholdings tax-exempt } \\
\text { Mandatory bid rule } \\
\text { Corporate governance code mandated on a comply-or-explain basis } \\
\text { Merger of securities and banking authorities } \\
\text { Criminal sanctions for market manipulation (2002) }\end{array}$ & $\begin{array}{l}\text { One-share one-vote rules } \\
\text { Control transactions } \\
\text { Corporate governance } \\
\text { Powers of supervisory authority } \\
\text { Sanctions against market abuse }\end{array}$ & $\begin{array}{l}\text { Shareholder empowerment } \\
\text { Shareholder empowerment } \\
\text { Disclosure } \\
\text { Public enforcement } \\
\text { Public enforcement }\end{array}$ \\
\hline 2003 & Civil actions for securities fraud made easier & Private enforcement & Shareholder empowerment \\
\hline 2004 & $\begin{array}{l}\text { Prohibition on nonaudit services to audit clients } \\
\text { Securities' agency review of financial reports } \\
\text { German "PCAOB" (2004) }\end{array}$ & $\begin{array}{l}\text { Financial reporting and auditing } \\
\text { Enforcing reporting and auditing rules } \\
\text { Enforcing reporting and auditing rules }\end{array}$ & $\begin{array}{l}\text { Disclosure } \\
\text { Public enforcement } \\
\text { Public enforcement }\end{array}$ \\
\hline 2006 & Annual disclosure of individual directors' compensation & Self-dealing and compensation & Disclosure \\
\hline
\end{tabular}


Table 3. France: National Corporate Governance Reforms

\begin{tabular}{|c|c|c|c|}
\hline Year & Reform content & Specific area & General area \\
\hline 1992 & Mandatory bid rule & Control transactions & Shareholder empowerment \\
\hline \multirow[t]{6}{*}{2001} & $\begin{array}{l}\text { Separation of Chairman and CEO allowed } \\
\text { New rules on board's information }\end{array}$ & $\begin{array}{l}\text { Board effectiveness } \\
\text { Board effectiveness }\end{array}$ & $\begin{array}{l}\text { Internal governance } \\
\text { Internal governance }\end{array}$ \\
\hline & $\begin{array}{l}\text { Board approval of nonroutine transactions with significant shareholders and of some } \\
\text { forms of executive compensation; board disclosure of nontrivial routine self-dealing } \\
\text { transactions mandated }\end{array}$ & Internal governance and self-dealing & Internal governance \\
\hline & $\begin{array}{l}\text { Annual ratification by shareholder meeting of nonroutine transactions with significant } \\
\text { shareholders and of some forms of executive compensations }\end{array}$ & Greater voice for shareholders & Shareholder empowerment \\
\hline & Exercise of voting rights made easier & Greater voice for shareholders & Shareholder empowerment \\
\hline & $\begin{array}{l}\text { Annual disclosure of nonroutine transactions with significant shareholders and of some } \\
\text { forms of executive compensation }\end{array}$ & Self-dealing and compensation & Disclosure \\
\hline & Annual disclosure of individual directors' compensation & Self-dealing and compensation & Disclosure \\
\hline 2002 & Lower thresholds for minority shareholder rights & Greater voice for shareholders & Shareholder empowerment \\
\hline \multirow[t]{6}{*}{2003} & New rules on board's information & Board effectiveness & Internal governance \\
\hline & $\begin{array}{l}\text { Board approval of nonroutine transactions with significant shareholders and of some } \\
\text { forms of executive compensation; board disclosure of nontrivial routine self-dealing } \\
\text { transactions mandated }\end{array}$ & Internal governance and self-dealing & Internal governance \\
\hline & $\begin{array}{l}\text { Annual ratification by shareholder meeting of nonroutine transactions with significant } \\
\text { shareholders and of some forms of executive compensations }\end{array}$ & Greater voice for shareholders & Shareholder empowerment \\
\hline & $\begin{array}{l}\text { Corporate governance report mandated; corporate governance code mandated on a } \\
\text { comply-or-explain basis }\end{array}$ & Corporate governance & Disclosure \\
\hline & $\begin{array}{l}\text { Annual disclosure of nonroutine transactions with significant shareholders and of some } \\
\text { forms of executive compensation }\end{array}$ & Self-dealing and compensation & Disclosure \\
\hline & $\begin{array}{l}\text { CEO abstains from proposals of auditors } \\
\text { Audit partner rotation, } 6 \text { years } \\
\text { Prohibition on nonaudit services to audit clients } \\
\text { Merger of securities and banking authorities } \\
\text { French "PCAOB" }\end{array}$ & $\begin{array}{l}\text { Financial reporting and auditing } \\
\text { Financial reporting and auditing } \\
\text { Financial reporting and auditing } \\
\text { Powers of supervisory authority } \\
\text { Enforcing reporting and auditing rules }\end{array}$ & $\begin{array}{l}\text { Disclosure } \\
\text { Disclosure } \\
\text { Disclosure } \\
\text { Public enforcement } \\
\text { Public enforcement }\end{array}$ \\
\hline \multirow[t]{2}{*}{2005} & $\begin{array}{l}\text { Board approval of nonroutine transactions with significant shareholders and of some } \\
\text { forms of executive compensation; board disclosure of nontrivial routine self-dealing } \\
\text { transactions mandated }\end{array}$ & Internal governance and self-dealing & Internal governance \\
\hline & $\begin{array}{l}\text { Annual ratification by shareholder meeting of nonroutine transactions with significant } \\
\text { shareholders and of some forms of executive compensations }\end{array}$ & Greater voice for shareholders & Shareholder empowerment \\
\hline
\end{tabular}

Source: Enriques and Volpin (2007). 
Table 4. EU Corporate Governance Reforms

\begin{tabular}{|c|c|c|}
\hline Year & Reform & Content \\
\hline \multirow[t]{2}{*}{2001} & Directive on the Admission of Securities to Official Stock Exchange Listings & \\
\hline & $\begin{array}{l}\text { Regulation on the Statute for a European Company } \\
\text { Directive supplementing the Statute for a European Company }\end{array}$ & \\
\hline 2002 & IAS/IFRS Regulation (+ 13 associated regulations) & $\begin{array}{l}\text { Requires EU companies listed in a European } \\
\text { regulated market to prepare consolidated } \\
\text { financial statements in accordance to } \\
\text { International Financial Reporting Standards } \\
\text { (IFRS) }\end{array}$ \\
\hline \multicolumn{3}{|c|}{ (implementation in 2006) } \\
\hline \multirow[t]{4}{*}{2003} & $\begin{array}{l}\text { Market Abuse Directive (MAD) + } 2 \text { associated directives and } 1 \text { regulation } \\
\text { Directive on Annual Accounts of Certain Types of Companies As Regards } \\
\text { Amounts Expressed in euros }\end{array}$ & Bans insider trading and market manipulation \\
\hline & $\begin{array}{l}\text { Directive on Annual and Consolidated Accounts of Certain Types of } \\
\text { Companies, Banks, and Other Financial Institutions and Insurance } \\
\text { Undertakings }\end{array}$ & \\
\hline & Directive on Disclosure Requirements & \\
\hline & Prospectus Directive (PD) & $\begin{array}{l}\text { Requires companies to disclose details of related- } \\
\text { party transactions }\end{array}$ \\
\hline \multirow[t]{2}{*}{2004} & Takeover Bids Directive (TBD) & $\begin{array}{l}\text { Aims to increase takeover activity. Focuses on: } \\
\text { (i) mandatory bid rule; (ii) board neutrality rule; } \\
\text { and (iii) break-through rule }\end{array}$ \\
\hline & Transparency Directive (TD) & $\begin{array}{l}\text { Requires shareholders to promptly notify } \\
\text { companies upon acquisitions or disposal of } \\
\text { shares in relation to relevant thresholds of voting } \\
\text { rights }\end{array}$ \\
\hline 2005 & Directive on Cross-Border Mergers of Limited Liability Companies & \\
\hline \multirow[t]{4}{*}{2006} & Directive on Statutory Audit & $\begin{array}{l}\text { Strenthens public oversight and auditors' } \\
\text { independence }\end{array}$ \\
\hline & $\begin{array}{l}\text { Directive on Annual Accounts of Certain Types of Companies and } \\
\text { Consolidated Accounts }\end{array}$ & \\
\hline & $\begin{array}{l}\text { Directive on Formation of Public Limited Liability Companies and the } \\
\text { Maintenance and Alteration of Their Capital }\end{array}$ & \\
\hline & Directive on the Exercise of Voting Rights & \\
\hline
\end{tabular}

Sources: Enriques and Gatti (2006); and European Commission. 
Table 5. Number of Dual-

Class Firms by Country $1 /$

(1992-2007 period average)

\begin{tabular}{lr}
\hline Canada & 49 \\
Denmark & 34 \\
Finland & 28 \\
France & 15 \\
Germany & 68 \\
Italy & 80 \\
Norway & 14 \\
Sweden & 32 \\
UK & 22 \\
$\quad$ Total & 342 \\
\hline
\end{tabular}

Source: DataStream

$1 /$ Includes firms with shares satsfying

conditions (a)-(e) in the

text.

Table 6. Voting Premium: Summary Statistics

(Sample average,1992-2007)

\begin{tabular}{lrrr}
\hline & Sample & \multicolumn{2}{c}{ Voting premium } \\
\cline { 3 - 4 } & size & Mean & Median \\
\hline & & & \\
Canada & 37,818 & 0.15 & 0.02 \\
Denmark & 24,384 & 0.13 & 0.01 \\
Finland & 21,227 & 0.13 & 0.03 \\
France & 2,653 & 0.50 & 0.20 \\
Germany & 52,038 & 0.11 & 0.09 \\
Italy & 63,204 & 0.46 & 0.31 \\
Norway & 11,699 & 0.04 & 0.02 \\
Sweden & 19,859 & 0.01 & 0.00 \\
UK & 17,928 & 0.31 & 0.19 \\
$\quad$ Overall & 250,810 & 0.21 & 0.06 \\
\hline
\end{tabular}


Table 7. Voting Premiums: Year Effects

The results of the fixed-effect estimations explaining the one-year lead in the voting premium with with year dummies and country dummies, as in equation (2)

\begin{tabular}{lrrr}
\hline Year dummy & Coef. & Std. err. & $P>|\mathrm{t}|$ \\
\hline yd93 & -0.073 & 0.006 & 0.000 \\
yd94 & -0.205 & 0.006 & 0.000 \\
yd95 & -0.218 & 0.006 & 0.000 \\
yd96 & -0.224 & 0.006 & 0.000 \\
yd97 & -0.246 & 0.006 & 0.000 \\
yd98 & -0.281 & 0.006 & 0.000 \\
yd99 & -0.262 & 0.006 & 0.000 \\
yd00 & -0.243 & 0.006 & 0.000 \\
yd01 & -0.284 & 0.006 & 0.000 \\
yd02 & -0.316 & 0.006 & 0.000 \\
yd03 & -0.339 & 0.006 & 0.000 \\
yd04 & -0.352 & 0.006 & 0.000 \\
yd05 & -0.338 & 0.006 & 0.000 \\
yd06 & -0.325 & 0.006 & 0.000 \\
yd07 & -0.306 & 0.006 & 0.000 \\
cons & 0.469 & 0.005 & 0.000 \\
$R$ within & 0.288 & & \\
$R 2$ between & 0.008 & & \\
$R 2$ overall & 0.19 & & \\
\hline
\end{tabular}

Table 8. Voting Premiums: Distributed Year Effects

The results of the fixed-effect estimations explaining the two- and three-year lead in the voting premium with with year dummies and country dummies, as in equation (2). Only results for reform-heavy years are shown.

\begin{tabular}{|c|c|c|c|}
\hline & Coef. & td. err. & $P>|t|$ \\
\hline & \multicolumn{3}{|c|}{ VP, 2-year lead } \\
\hline yd98 & -0.291 & 0.008 & 0.000 \\
\hline yd01 & -0.297 & 0.008 & 0.000 \\
\hline yd02 & -0.329 & 0.008 & 0.000 \\
\hline yd03 & -0.352 & 0.008 & 0.000 \\
\hline yd04 & -0.363 & 0.008 & 0.000 \\
\hline yd05 & -0.350 & 0.008 & 0.000 \\
\hline yd06 & -0.332 & 0.008 & 0.000 \\
\hline _cons & 0.476 & 0.006 & 0.000 \\
\hline$R$ within & 0.018 & & \\
\hline R2 between & 0.192 & & \\
\hline \multirow[t]{2}{*}{ R2 overall } & 0.190 & & \\
\hline & \multicolumn{3}{|c|}{ VP, 3-year lead } \\
\hline yd98 & -0.291 & 0.008 & 0.000 \\
\hline yd01 & -0.297 & 0.008 & 0.000 \\
\hline yd02 & -0.328 & 0.008 & 0.000 \\
\hline yd03 & -0.351 & 0.008 & 0.000 \\
\hline yd04 & -0.363 & 0.008 & 0.000 \\
\hline yd05 & -0.350 & 0.008 & 0.000 \\
\hline yd06 & -0.332 & 0.008 & 0.000 \\
\hline _cons & 0.476 & 0.006 & 0.000 \\
\hline$R$ within & 0.018 & & \\
\hline R2 between & 0.192 & & \\
\hline R2 overall & 0.190 & & \\
\hline
\end{tabular}


Table 9. Relative Effectiveness of Reforms in C3 Compared to the EU and Non-EU Peers, by Year

The results of the fixed-effect estimations explaining the one-year lead in the voting premium with interaction dummies between country and year. EU control group includes Denmark, Finland, Sweden, and the UK, while nonEU control group includes Canada and Norway. Reported are the years with significant number of reforms. Estimation specification as in equation (3).

\begin{tabular}{|c|c|c|c|}
\hline & Coef. & Std. err. & $\mathrm{P}>|\mathrm{z}|$ \\
\hline & & 1998 & \\
\hline France & 0.061 & 0.087 & 0.482 \\
\hline Germany & -0.018 & 0.009 & 0.041 \\
\hline Italy & -0.029 & 0.008 & 0.001 \\
\hline Control group & -0.006 & & \\
\hline EU & -0.039 & 0.015 & 0.181 \\
\hline \multirow[t]{2}{*}{ non-EU } & 0.008 & 0.020 & 0.692 \\
\hline & & 2001 & \\
\hline France & -0.203 & 0.050 & 0.000 \\
\hline Germany & -0.005 & 0.009 & 0.596 \\
\hline Italy & -0.171 & 0.008 & 0.000 \\
\hline Control group & -0.084 & & \\
\hline EU & 0.043 & 0.014 & 0.197 \\
\hline \multirow[t]{2}{*}{ non-EU } & 0.008 & 0.019 & 0.694 \\
\hline & & 2002 & \\
\hline France & -0.601 & 0.038 & 0.000 \\
\hline Germany & -0.041 & 0.009 & 0.000 \\
\hline Italy & -0.276 & 0.008 & 0.000 \\
\hline Control group & -0.220 & & \\
\hline EU & 0.038 & 0.014 & 0.179 \\
\hline \multirow[t]{2}{*}{ non-EU } & -0.028 & 0.019 & 0.140 \\
\hline & & 2003 & \\
\hline France & -0.519 & 0.034 & 0.000 \\
\hline Germany & -0.078 & 0.009 & 0.000 \\
\hline Italy & -0.324 & 0.008 & 0.000 \\
\hline Control group & -0.218 & & \\
\hline EU & 0.049 & 0.014 & 0.023 \\
\hline \multirow[t]{2}{*}{ non-EU } & -0.035 & 0.019 & 0.069 \\
\hline & & 2004 & \\
\hline France & -0.297 & 0.034 & 0.000 \\
\hline Germany & -0.074 & 0.009 & 0.000 \\
\hline Italy & -0.335 & 0.008 & 0.000 \\
\hline Control group & -0.165 & & \\
\hline EU & 0.045 & 0.014 & 0.096 \\
\hline \multirow[t]{2}{*}{ non-EU } & 0.002 & 0.019 & 0.919 \\
\hline & & 2005 & \\
\hline France & -0.096 & 0.032 & 0.003 \\
\hline Germany & -0.057 & 0.009 & 0.000 \\
\hline Italy & -0.310 & 0.008 & 0.000 \\
\hline Control group & -0.104 & & \\
\hline EU & 0.049 & 0.014 & 0.359 \\
\hline \multirow[t]{2}{*}{ non-EU } & 0.033 & 0.019 & 0.083 \\
\hline & & 2006 & \\
\hline France & 0.292 & 0.029 & 0.000 \\
\hline Germany & -0.037 & 0.009 & 0.000 \\
\hline Italy & -0.286 & 0.008 & 0.000 \\
\hline Control group & 0.001 & & \\
\hline EU & 0.037 & 0.014 & 0.305 \\
\hline non-EU & 0.110 & 0.019 & 0.000 \\
\hline
\end{tabular}


Table 10. Relative Effectiveness of Reforms Compared to Control Groups: A Summary

\begin{tabular}{lcc}
\hline & \multicolumn{2}{c}{ More effective than for the control group? } \\
\cline { 2 - 3 } & EU & non-EU \\
\hline Italy & yes & yes \\
France & no & no \\
Germany & yes & yes \\
Italy & $2001-05$ & yes \\
France & yes, significantly & yes \\
Germany & yes & yes \\
& yes & \\
Italy & yes & yes \\
France & no, wrong direction & yes, but wrong \\
& & direction of the control \\
Germany & yes & yes \\
\hline
\end{tabular}

Table 11. Voting Premiums: Year Effects, Accounting for Product Market Reforms

The results of the fixed-effect estimations explaining the one-year lead in the voting premium with with year dummies, country dummies, and the idnex of product market reforms (PMR)

\begin{tabular}{lrrr}
\hline vp & Coef. & Std. err. & $P>|\mathrm{t}|$ \\
\hline yd93 & -0.005 & 0.006 & 0.392 \\
yd94 & -0.094 & 0.006 & 0.000 \\
yd95 & -0.035 & 0.007 & 0.000 \\
yd96 & -0.002 & 0.007 & 0.804 \\
yd97 & 0.009 & 0.007 & 0.187 \\
yd98 & 0.004 & 0.007 & 0.635 \\
yd99 & 0.104 & 0.008 & 0.000 \\
yd00 & 0.174 & 0.009 & 0.000 \\
yd01 & 0.180 & 0.009 & 0.000 \\
yd02 & 0.211 & 0.010 & 0.000 \\
yd03 & 0.206 & 0.010 & 0.000 \\
yd04 & $\ldots$ & & \\
yd05 & $\ldots$ & & \\
yd06 & $\ldots$ & & \\
yd07 & $\ldots$ & & \\
PMR & 0.238 & 0.004 & 0.000 \\
cons & -0.548 & 0.016 & 0.000 \\
$R$ within & 0.150 & & \\
$R 2$ between & 0.172 & & \\
$R 2$ overall & 0.173 & & \\
\hline
\end{tabular}


Table 12. Relative Effectiveness of Reforms in C3 Compared to the EU and Non-EU peers, Accounting for Product Market Reforms, by Year

The results of the fixed-effect estimations explaining the one-year lead in the voting premium with interaction dummies between country and year. EU control group includes Denmark, Finland, Sweden, and the UK, while nonEU control group includes Canada and Norway. Reported are the years with significant number of reforms. PMR is a product market reform index. Estimation specification is as in equation (3), with PMR included.

\begin{tabular}{|c|c|c|c|}
\hline $\mathrm{vp}$ & Coef. & Std. err. & $\mathrm{P}>|\mathrm{z}|$ \\
\hline & \multicolumn{3}{|c|}{1998} \\
\hline PMR & 0.133 & 0.002 & 0.000 \\
\hline France & -0.023 & 0.087 & 0.793 \\
\hline Germany & -0.034 & 0.009 & 0.000 \\
\hline Italy & -0.202 & 0.008 & 0.000 \\
\hline \multicolumn{4}{|c|}{ Control group } \\
\hline EU & -0.019 & 0.014 & 0.356 \\
\hline \multirow[t]{2}{*}{ non-EU } & 0.013 & 0.019 & 0.488 \\
\hline & \multicolumn{3}{|c|}{2001} \\
\hline PMR & 0.131 & 0.002 & 0.000 \\
\hline France & 0.065 & 0.051 & 0.201 \\
\hline Germany & 0.094 & 0.009 & 0.000 \\
\hline Italy & -0.139 & 0.008 & 0.000 \\
\hline \multicolumn{4}{|c|}{ Control group } \\
\hline EU & 0.076 & 0.014 & 0.205 \\
\hline \multirow[t]{2}{*}{ non-EU } & 0.081 & 0.019 & 0.000 \\
\hline & \multicolumn{3}{|c|}{2002} \\
\hline PMR & 0.128 & 0.002 & 0.000 \\
\hline France & -0.050 & 0.042 & 0.240 \\
\hline Germany & 0.083 & 0.009 & 0.000 \\
\hline Italy & -0.180 & 0.009 & 0.000 \\
\hline \multicolumn{4}{|c|}{ Control group } \\
\hline EU & 0.092 & 0.014 & 0.000 \\
\hline \multirow[t]{2}{*}{ non-EU } & 0.071 & 0.019 & 0.000 \\
\hline & \multicolumn{3}{|c|}{2003} \\
\hline PMR & 0.127 & 0.002 & 0.000 \\
\hline France & -0.003 & 0.042 & 0.941 \\
\hline Germany & 0.057 & 0.009 & 0.000 \\
\hline Italy & -0.218 & 0.009 & 0.000 \\
\hline \multicolumn{4}{|c|}{ Control group } \\
\hline EU & 0.124 & 0.014 & 0.000 \\
\hline non-EU & 0.092 & 0.019 & 0.000 \\
\hline
\end{tabular}

Note: 2004-06 dropped due to collinearity. 
Table 13. Distribution Characteristics of Voting Premiums, Pooled for All EU Countries

\begin{tabular}{lrrrrr}
\hline Year & Mean & Std. err. & & 95\% Conf. Interval \\
\cline { 1 - 2 } \cline { 6 - 6 } 1992 & 0.492 & 0.0125 & & 0.468 & 0.517 \\
1993 & 0.413 & 0.0109 & & 0.392 & 0.434 \\
1994 & 0.276 & 0.0063 & & 0.263 & 0.288 \\
1995 & 0.260 & 0.0054 & & 0.250 & 0.271 \\
1996 & 0.246 & 0.0051 & & 0.237 & 0.256 \\
1997 & 0.224 & 0.0045 & & 0.215 & 0.232 \\
1998 & 0.184 & 0.0039 & & 0.177 & 0.192 \\
1999 & 0.201 & 0.0039 & & 0.193 & 0.209 \\
2000 & 0.220 & 0.0042 & & 0.212 & 0.229 \\
2001 & 0.176 & 0.0040 & & 0.168 & 0.184 \\
2002 & 0.144 & 0.0045 & & 0.135 & 0.152 \\
2003 & 0.121 & 0.0041 & & 0.113 & 0.129 \\
2004 & 0.108 & 0.0038 & & 0.100 & 0.115 \\
2005 & 0.121 & 0.0040 & & 0.113 & 0.129 \\
2006 & 0.138 & 0.0045 & & 0.129 & 0.147 \\
2007 & 0.180 & 0.0064 & 0.168 & 0.193 \\
\hline
\end{tabular}


Figure 1. Dynamics of the Voting Premiums Across Countries, 1992-2007 (Annual averages)
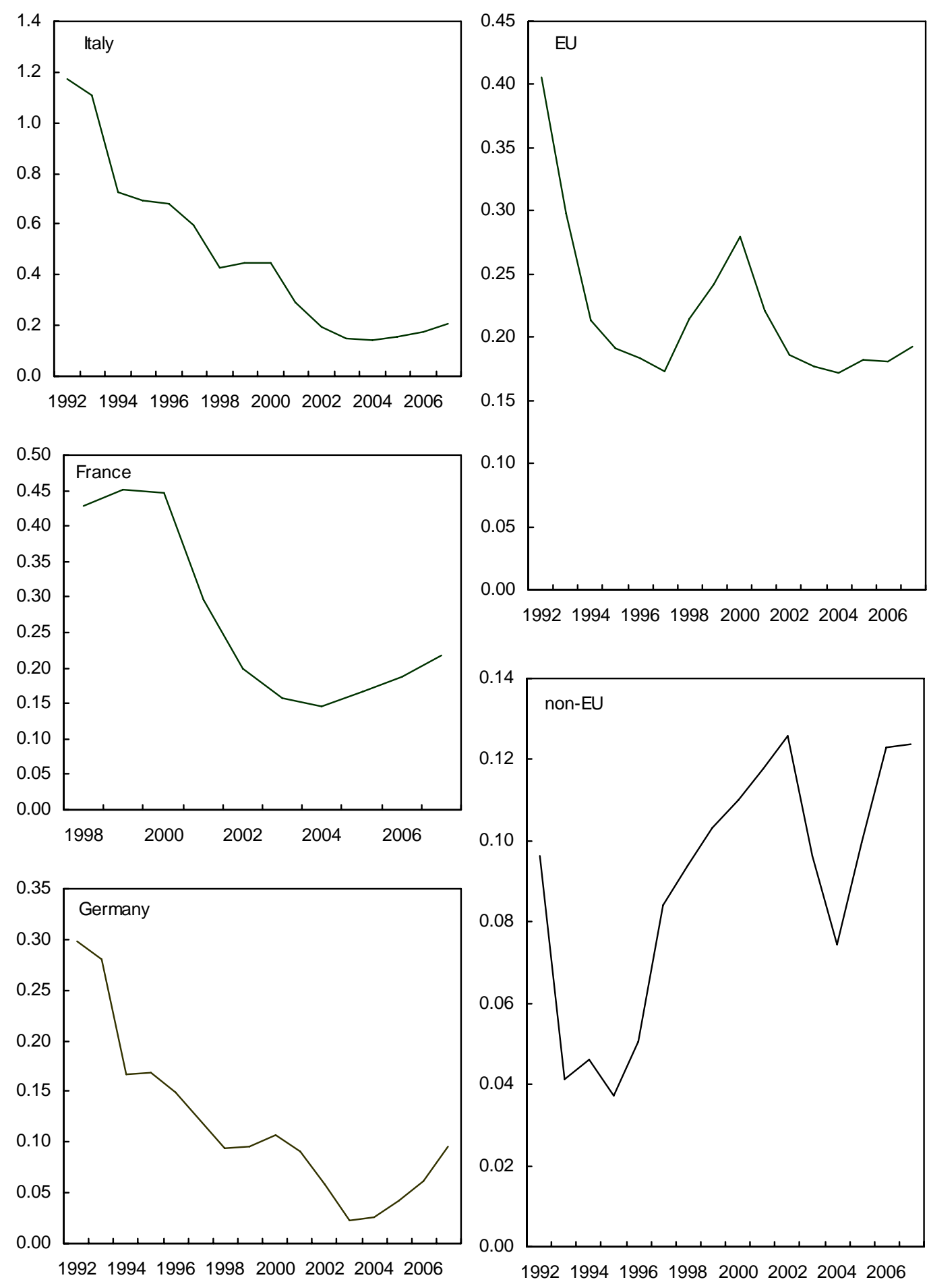

19921994199619982000200220042006

19921994199619982000200220042006

Sources: DataStream; and IMF staff calculations. 
Figure 2. Reform Efforts: Number of Important Corporate Governance Reforms Per Year
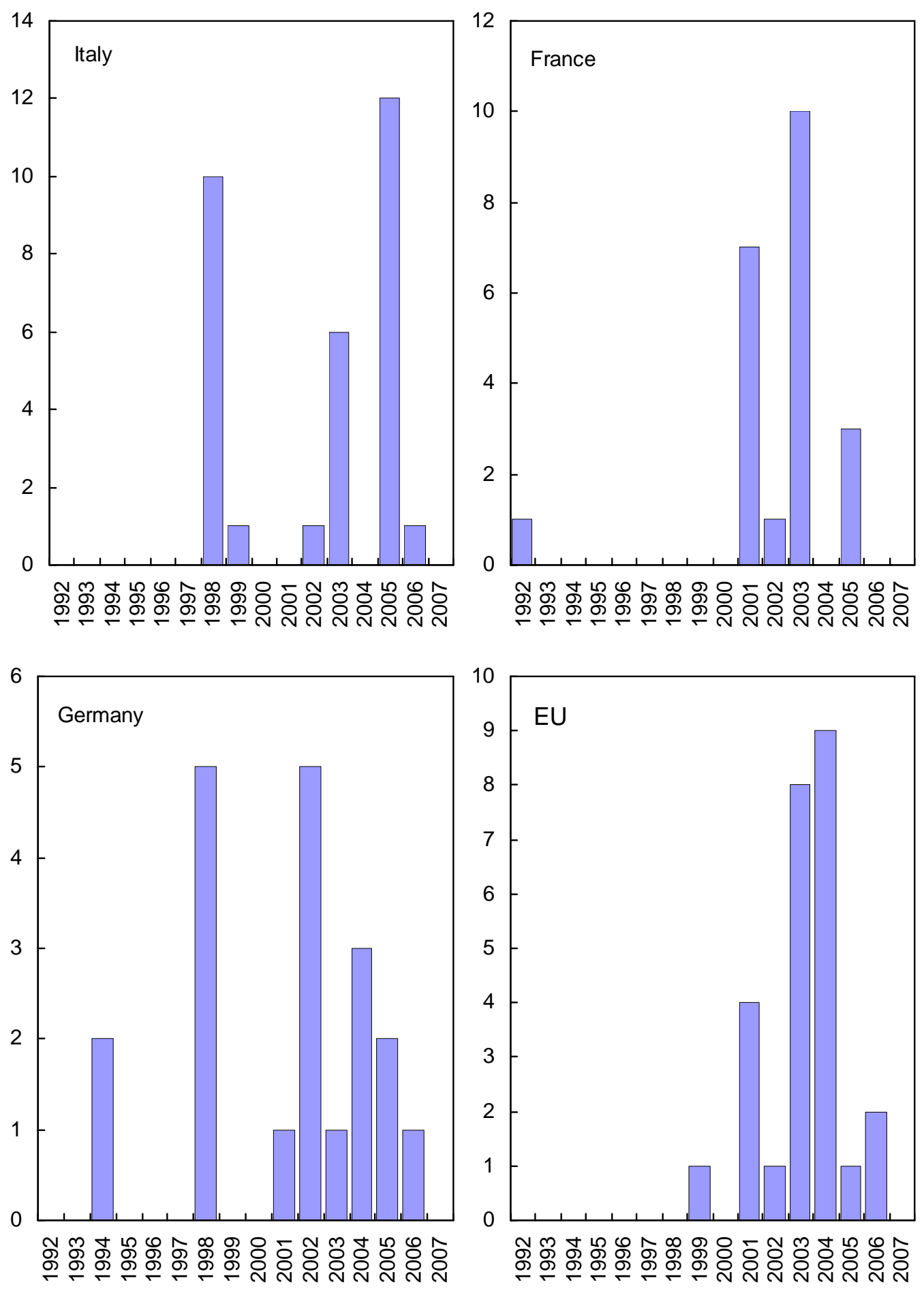

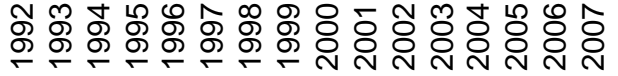

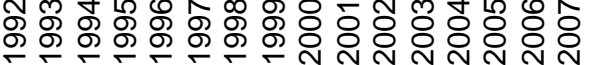

Source: Enrique and Volpin (2007). 
Figure 3. Number of National and EU Corporate Governance Reforms 1/

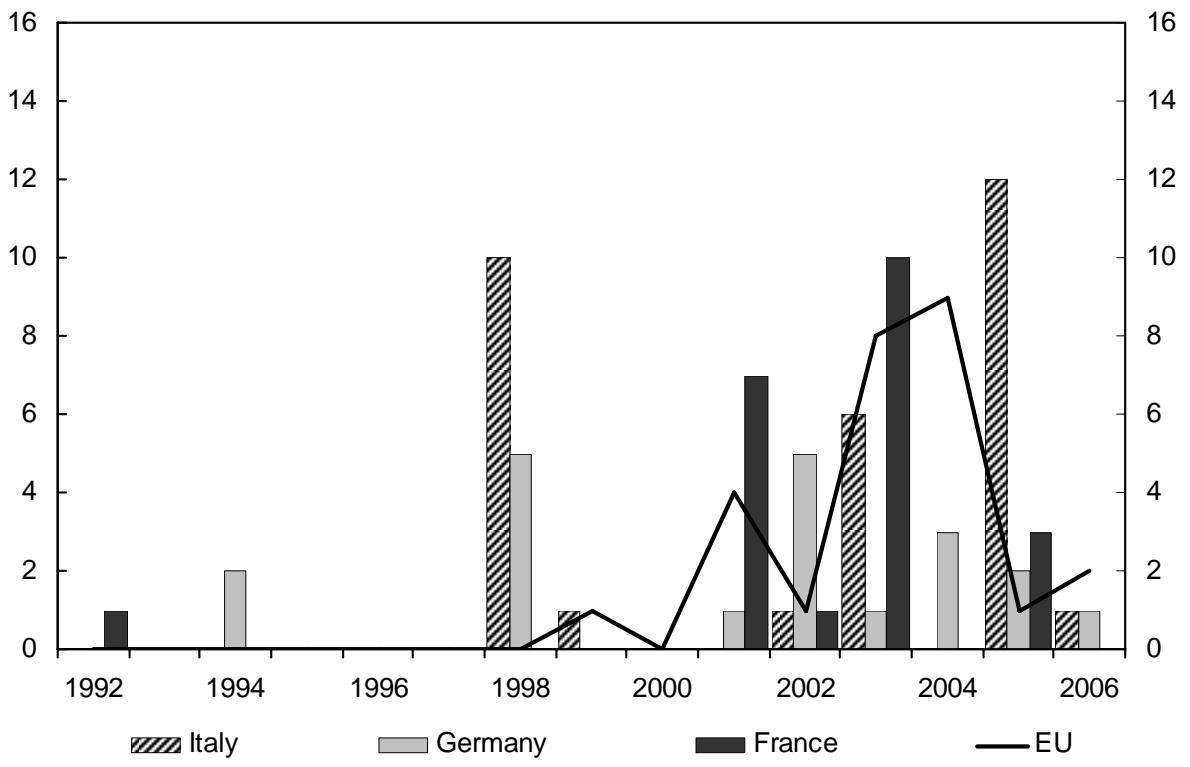

Sources: Enriques and Volpin (2007); Enriques and Gatti (2006); and IMF staff calculations.

1/ EU refers to reforms introduced in all EU countries.

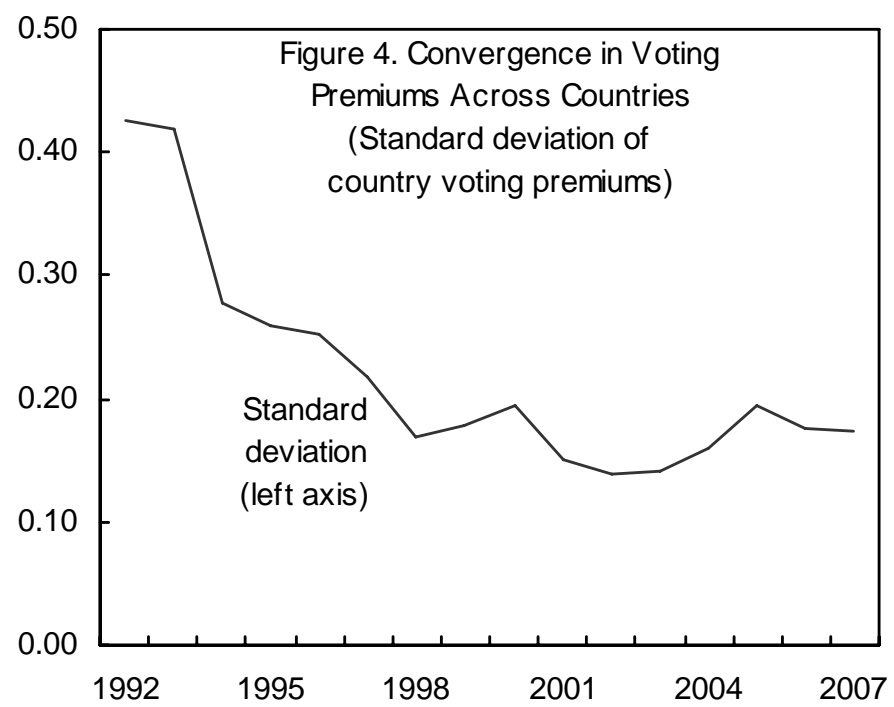


Figure 5. Distribution of Voting Premiums Across EU Countries, by Year

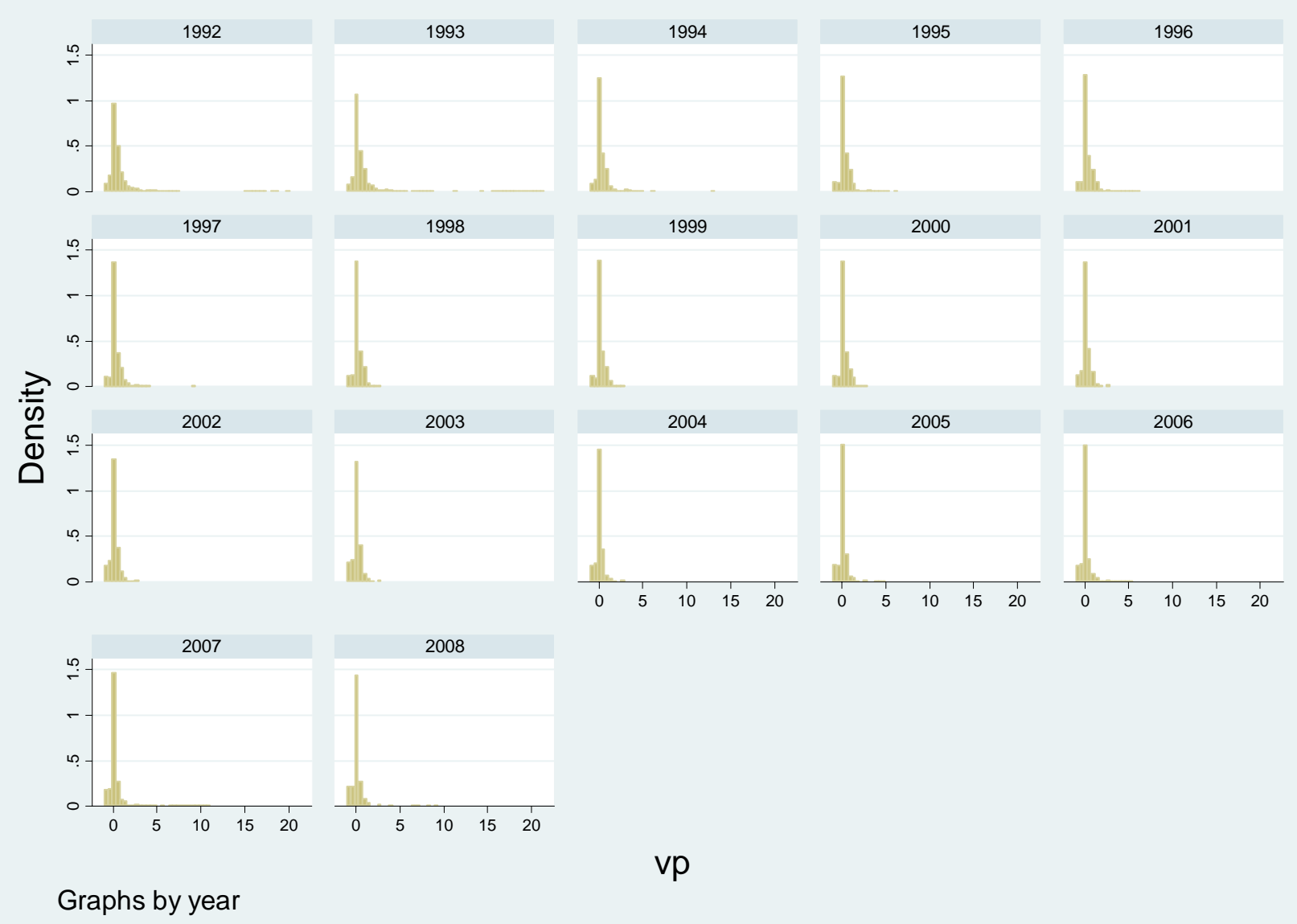

